\title{
O Ministério Público e a fiscalização da constitucionalidade de normas jurídicas no direito luso-brasileiro
}

\author{
Eduardo Diniz Neto ${ }^{1}$
}

\section{Introdução}

\subsection{Questões gerais}

O tema do presente trabalho respeita ao Ministério Público e a Constituição, precisamente sobre o controle da constitucionalidade de normas jurídicas por esse órgão de soberania nos dois países mais representativos da comunidade internacional de nações de língua portuguesa, com maior ênfase para o sistema vigente no direito lusitano, a fim de trazer, ainda que pareça pretensioso, pequena contribuição para uma aquisição válida e profícua, como se convenciona dizer em direito comparado.

Tratar-se-á, sistematicamente, numa abordagem sintetizada e objetiva, priorizada neste esquema de informação articulada, da estrutura organizatória e do plano funcional do Ministério Público em Portugal e no Brasil, com destaque para a defesa primordial da legalidade democrática e da Constituição através dos mecanismos normativos dos quais dispõe legitimamente o parquet para tanto.

Aliás, impende destacar, desde logo, que a Constituição Federal brasileira de 1988, ao também erigir o Ministério Público à categoria de instituição destinada "à defesa do regime democrático" (art. 127), retomou a idéia que já vinha do anteprojeto Afonso Arinos e da Carta de Curitiba - aprovada no 1을 Encontro Nacional de Procuradores-Gerais de Justiça e Presidentes de Associações do Ministério Público, realizado em junho de 1986, na capital do Estado do Paraná -, cuja inspiração foi haurida da Constituição da República Portuguesa de

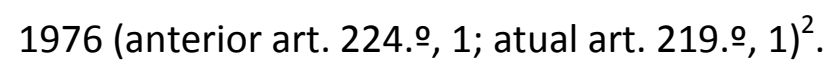

Serão, portanto, ao longo da exposição que se segue, não obstante as naturais imperfeições e limitações do autor, abordadas e lançadas à discussão as questões que se

\footnotetext{
Promotor de Justiça no Estado do Paraná. Professor do Departamento de Direito Público da Universidade Estadual de Londrina e da Fundação Escola do Ministério Público do Paraná, núcleo descentralizado de Londrina. Mestre pela Faculdade de Direito da Universidade de Coimbra.

2 MAZZILLI, Hugo Nigro. Manual do Promotor de Justiça. 2a ed. São Paulo: Saraiva, 1991, p. 5.
} 
afigurarem necessárias e oportunas nesse domínio, iniciando-a, para uma melhor compreensão, por um panorama das funções, estatuto e estrutura do Ministério Público nos países irmãos.

\subsection{Funções, estatuto e estrutura do Ministério Público. Quadro legislativo fundamental de Portugal e Brasil}

O Ministério Público formou-se lenta e progressivamente em resposta às exigências históricas. E a instituição, tal qual a conhecemos hoje, é relativamente recente.

Em Portugal, no sistema pré-constitucional de 1976, o Ministério Público funcionava no escalão inferior como estágio vestibular da carreira judicial, sendo os escalões superiores preenchidos por juízes. Havia apenas uma separação funcional ${ }^{3}$.

Atualmente, o texto da Carta Magna, já operada a revisão através da Lei Constitucional n.o 1/97, de 20 de Setembro, estabelece nos seus Arts. 219ㅇ e 220ㅇ as regras genéricas sobre as funções, estatuto e estrutura do Ministério Público, os quais são detalhadamente descritos na Lei n.o 47/86, de 15 de Outubro (Estatuto do Ministério Público), com as ulteriores e necessárias adaptações.

Assim, as funções do Ministério Público são precipuamente consagradas no Art. 219.ำ n. 1, da Constituição da República Portuguesa, onde se destacam as áreas de representação do Estado, nomeadamente nos tribunais, em causas em que ele seja parte, funcionando como espécie de advogado do Estado; exercício da ação penal orientada pelo princípio da legalidade; defesa da legalidade democrática, intervindo, v. g., no contencioso administrativo e fiscal, bem como na fiscalização da constitucionalidade; defesas dos interesses de determinadas pessoas consideradas hipossuficientes, mediante a ocorrência de certos requisitos previstos em leis ordinárias, tais como os incapazes, órfãos, ausentes, os trabalhadores, etc., passando também pela defesa de interesses difusos (ambiente, patrimônio público, etc.), a que a quarta revisão da Constituição acrescentou uma função de relevante significado político e jurídico-constitucional: a da participação na execução da política criminal definida pelos órgãos de soberania. Às funções supra consignadas deve

3 CANOtILHO, J.J. Gomes; MOREIRA, Vital. Constituição da República Portuguesa Anotada, 3.a ed. Coimbra: Coimbra Editora, 1993, p. 830. 
ainda somar-se a importante função consultiva, traduzida na emissão de pareceres por parte da Procuradoria-Geral da República ${ }^{4}$.

Tais funções genéricas são estabelecidas pormenorizadamente nos Arts. 1. (definição) e 3.ㅇ (competência) da Lei n. 47/86, e caracterizam-se, grosso modo, pelo seu exercício no interesse público, mas que, quando confrontadas com a atribuição de defesa dos interesses privados do Estado, podem gerar conflitos nem sempre harmonizáveis. Em Portugal, portanto, diferentemente do que ocorre em outros países, dentre os quais se inclui o Brasil, o Ministério Público continua a ser também uma espécie de advogado do Estado em determinadas situações, não havendo procuradores distintos para o patrocínio daqueles interesses.

Sem embargo de ser o Ministério Público, nos termos constitucionais, um órgão do poder judicial, determinou a Carta de 76, como já salientado, a separação entre a magistratura judicial e a do Ministério Público, implicando a separação dos respectivos corpos e também s existência de carreiras autônomas.

Goza, assim, o Ministério Público de estatuto próprio e autonomia em relação aos demais órgãos do poder central, regional e local (Art. 219., n.ㅇ 2, CRP, c/c. o Art. 2.ㅇ da Lei 47/86). E a autonomia vale, insista-se, face ao Governo e também face à magistratura judicial. "Na sua primeira vertente ela significa que ele não depende hierarquicamente do Governo, o qual the não pode dirigir ordens ou instruções, nem influir no respectivo governo e administração" ${ }^{5}$.

Caracteriza-se essa autonomia, ademais, pela sua vinculação a critérios de legalidade e objetividade, bem como pela exclusiva sujeição de seus magistrados às diretivas, ordens e instruções previstas no estatuto da instituição.

É no estatuto do Ministério Público que também são definidos os requisitos para acesso à magistratura, representação, direitos, deveres, os regimes de intervenção nos processos - principal e acessória (Arts. 4.ํ a 6.ํ) -, de acordo com a respectiva lei adjetiva, etc..

A responsabilidade e a hierarquia (Art. 219ㅇ, n.o 4), contrariamente ao que ocorre com os juízes (irresponsabilidade e independência, cf. Art. 216.ํ, CRP), caracterizam o

\footnotetext{
4 Cf. FONSECA, Guilherme Frederico da; LACERDA, Dimas de; e CUNHA RODRIGUES. Apud CANOTILHO, J. J. Gomes. Direito Constitucional e Teoria da Constituição. 2.a ed. Coimbra: Almedina, 1998, p. 597.

5 CANOTILHO, J.J. Gomes; e MOREIRA, Vital. Direito Constitucional... Op.cit.., p. 830.
} 
Ministério Público, o que, entretanto, não retira ou diminui as garantias de autonomia e independência de seus agentes, dado o paralelismo à magistratura judicial que os coloca em igual posição de sujeição à lei (Art. 203.ำ, CRP).

A responsabilidade consiste em responderem os agentes do Ministério Público, nos termos da lei, pelo cumprimento dos seus deveres e pela observância das diretivas, ordens e instruções que receberem. A hierarquia consiste na subordinação dos magistrados aos de grau superior, nos termos do estatuto do Ministério Público, e na conseqüente obrigação de acatamento por aqueles das diretivas, ordens ou instruções, sem prejuízo do disposto nos Arts. 79. (limites aos poderes diretivos) e 80. (poderes do Ministro da Justiça), ambos da Lei n. 0 47/86.

A Procuradoria-Geral da República é o órgão superior do Ministério Público (Art. 220.ํ, CRP), com a composição e competência definidos no estatuto (Art. 9.ํ e ss.). 0 Procurador-Geral da República preside este órgão superior e sua nomeação (ou exoneração) dá-se, sob proposta do Governo, pelo Presidente da República (Art. 133.o, m), CRP). A estrutura e composição do gabinete do Procurador-Geral, entretanto, são definidos em diploma próprio (Art. 2.ํ, n.으 5, Lei n. 47/86).

A inamovibilidade, por sua vez, aproxima o estatuto do Ministério Público do dos juízes, na medida em que garante também aos seus magistrados a impossibilidade de serem transferidos, suspensos, promovidos, aposentados ou, por qualquer forma, mudados de situação, salvo nos casos previstos em lei e mediante adequada justificação dos motivos (Art. 219.ํ, n.․ 4, CRP).

Para finalizar esta rápida incursão pelos traços gerais do Ministério Público lusitano, convém registrar que são órgãos da instituição: a) a Procuradoria-Geral da República; $b$ ) As procuradorias-gerais distritais; e c) as procuradorias da República (Art. 7.․, estatuto do MP). E são seus agentes: a) o Procurador-Geral da República; b) o Vice-Procurador-Geral da República; c) os procuradores-gerais adjuntos; d) os procuradores da República; e e) os procuradores-adjuntos, todos podendo ser coadjuvados por assessores, nos termos da lei

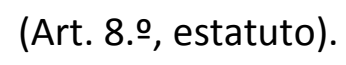

No Brasil, o Ministério Público, com o advento da Constituição federal democrática de 1988, ocupa lugar de destaque na organização do Estado, como órgão de soberania tal qual em Portugal, principalmente dado o alargamento de suas funções de proteção de 
direitos indisponíveis e de interesses coletivos. Assim, o Art. 127 da Constituição Federal dáIhe o relevo de <<instituição permanente, essencial à função jurisdicional do Estado, incumbindo-lhe a defesa da ordem jurídica, do regime democrático e dos interesses sociais individuais indisponíveis >>, conceito repetido no Art. 1으 da Lei n.o 8.625, de 12 de fevereiro de 1993 (Lei Orgânica Nacional do Ministério Público).

Embora haja alguns defensores mais exaltados da instituição que a queiram elevar a um quarto poder do Estado, exsurge possuir ela atribuições ontologicamente de natureza executiva, funcionalmente independente, cujos membros integram a categoria de agentes políticos e, como tal, hão de atuar "com plena liberdade funcional, desempenhando suas atribuições com prerrogativas e responsabilidades próprias, estabelecidas na Constituição e em leis especiais. Não são funcionários públicos em sentido estrito, nem se sujeitam ao regime estatutário comum. Têm normas específicas para sua escolha, investidura, conduta e processo por crimes funcionais e de responsabilidade, que lhes são privativos" ${ }^{6}$.

Dentro dessa orientação normativo-constitucional, foram consagrados os princípios institucionais da unidade, da indivisibilidade, e da independência funcional, que asseguram, ademais, ao Ministério Público autonomia administrativa, facultando-lhe, inclusive, propor ao Poder Legislativo a criação e extinção de seus cargos e serviços auxiliares, provendo-os por concurso público de provas e de provas e títulos. Possui, também, o poder de iniciativa de lei nessas matérias, além de elaborar sua proposta orçamentária dentro dos limites estabelecidos na lei de diretrizes orçamentárias.

Antes de avançarmos, convém destacar que, dado o federalismo que vige no Brasil, a estrutura orgânica, estatuto e atribuições de seu Ministério Público são regulados genericamente na Constituição Federal e Constituições Estaduais, detalhados, porém, na Lei Orgânica Nacional supra referida, a qual, por sua vez, dispõe sobre normas gerais para organização do MP nos Estados e dá outras providências, a par da Lei Orgânica do Ministério Público da União e das Leis Orgânicas de cada uma das instituições das unidades federativas, que englobam normas específicas também de organização, atribuições e estatuto do respectivo MP.

6 Cf. MEIRELLES, Hely Lopes. Apud SILVA, José Afonso da. Curso de Direito Constitucional Positivo. 9a ed. São Paulo: Malheiros, 1992, p. 511. 
Assim, em relação à estrutura orgânica, diz o Art. 128 da Constituição Federal que o Ministério Público abrange: I - O Ministério Público da União, que compreende: a) o Ministério Público Federal; b) o Ministério Público do Trabalho; c) o Ministério Público Militar; d) o Ministério Público do Distrito Federal; II - O Ministério Público dos Estados. E o Art. 130 admite um Ministério Público especial junto aos Tribunais de Contas, órgãos não jurisdicionais.

O Ministério Público da União é chefiado pelo Procurador-Geral da República, nomeado pelo Presidente da República dentre integrantes da carreira, maiores de trinta e cinco anos, após a aprovação de seu nome pela maioria absoluta do Senado Federal, para mandato de dois anos, permitida a recondução, obedecido o mesmo procedimento, sem limitação do número de reconduções. Por outro lado, os Ministérios dos Estados e do Distrito Federal formarão lista tríplice dentre integrantes da carreira, que é formada pelo escrutínio de todos os membros, na forma da lei respectiva, para a escolha do ProcuradorGeral de Justiça, chefe da instituição nas unidades federativas (Art. 128, § 1으, CF). Este Procurador-Geral, é nomeado pelo Governador do Estado, após deliberação da maioria absoluta do Poder Legislativo local (Assembléia Legislativa), para mandato de dois anos, permitida uma recondução, observado o mesmo procedimento (Art. 128, § 3ㅇ, CF; e Art. 9으, Lei Orgânica Nacional do MP).

Passemos, a seguir, à análise sucinta dos princípios que informam a estrutura orgânica do Ministério Público brasileiro, vale dizer, os princípios da unidade, da indivisibilidade e da autonomia funcional.

Segundo o princípio da autonomia funcional, o Ministério Público tem a independência no exercício de suas funções (Art. 127, §§ 1으 e 2ํ, CF). E em face das peculiaridades do Ministério Público brasileiro, hierarquia, portanto, "só se concebe num sentido administrativo, pela natural chefia exercida na instituição pelo seu procurador-geral (poderes de designação, na forma da lei; disciplina funcional; solução de conflitos de atribuição, etc.). Não se pode cogitar, porém, de hierarquia no sentido funcional”" ${ }^{7}$. Não se pode impor um procedimento funcional a um órgão do Ministério Público, senão fazendo recomendação sem caráter normativo, pois a Constituição e a Lei Orgânica, antes de

7 MAZZILLI, Hugo Nigro. Manual... Op. cit., p. 47. 
assegurar aos seus membros garantias pessoais, deram-lhes garantias funcionais, para que possam servir aos interesses da lei, e não dos governantes.

Pelos princípios da unidade e da indivisibilidade quer-se significar que a instituição do Ministério Público abrange todos os Ministérios Públicos indicados no Art. 128 da Constituição Federal. Assim, quer atue no plano federal, junto à justiça comum ou especial, quer atue no plano dos Estados e Distrito Federal, o Ministério Público é uma só instituição em seus lineamentos básicos.

Entretanto, tais princípios devem ser analisados sob o contexto da organização federativa, através do qual pode-se afirmar a existência de um parquet em cada Estado, para além do que constitui o Ministério Público da União e dos que funcionam junto a jurisdições especiais.

Em suma, pode-se, assim, dizer que a unidade significa que os agentes do Ministério Público de um Estado, p. ex., integram um só órgão sob a direção de um só chefe. A indivisibilidade, por seu turno, significa que seus membros podem ser substituídos uns pelos outros, de forma transparente e estabelecida em lei, observada a instituição como um corpo hierarquizado.

Quanto às garantias, como agentes políticos que são, os membros do Ministério Público possuem as prerrogativas da vitaliciedade, irredutibilidade de vencimentos e inamovibilidade (Art. 128, §5으, I, CF). Tais garantias, longe de serem privilégios pessoais, consubstanciam o imprescindível resguardo para o desempenho, com ampla liberdade, de suas relevantes e diversificadas atribuições. Pela vitaliciedade, uma vez tornado vitalício, isto é, titular do cargo por toda a vida, ultrapassado com aproveitamento o estágio probatório da carreira, o membro do Ministério Público só pode dela se afastar por vontade própria e apenas o perderá por sentença judicial transitada em julgado, ou aposentadoria (reforma) compulsória ou disponibilidade. A inamovibilidade refere-se à permanência do agente no cargo para o qual foi nomeado, salvo remoção por interesse público na forma da lei orgânica. E a irredutibilidade dos vencimentos quer dizer que os vencimentos dos membros do Ministério Público, tal como ocorre com os magistrados judiciais, não podem ser diminuídos nem mesmo em virtude de medida geral, observados os limites legais. 
Incidem, ainda, na sua atuação as garantias de imparcialidade na forma de vedações (Art. 128, § 5.ㅇ, II, CF), dentre os quais, v. g., a de exercer, ainda que em disponibilidade, qualquer outra função pública, salvo uma de magistério.

As funções institucionais gerais do Ministério Público estão relacionadas no Art. 129 da Constituição Federal e Arts. 25 a 27 da Lei n.o 8.625/93. E ai aparece, essencialmente, como: titular da ação penal, da ação civil pública para a tutela dos interesses públicos, coletivos, sociais e difusos, e da ação direta de inconstitucionalidade genérica e interventiva, nos termos da Constituição Federal; garantidor do respeito aos Poderes Públicos e aos serviços de relevância pública; defensor dos direitos e interesses das populações indígenas; de intervenção em procedimentos administrativos; de controle externo da atividade policial; de requisição de diligências investigatórias e de instauração do inquérito policial. Compete ao Ministério Público, ainda, junto aos Tribunais de Contas, o exercício de suas funções somente como custos legis. Isto porque, ao contrário do que sucede em Portugal, a representação da União, Estados e Municípios, bem como em qualquer outro caso, cabe aos respectivos procuradores (advogados), nos termos delineados nos Arts. 131 e ss. também da Constituição Federal. E é claro que há as funções, mormente na esfera cível, de família e da infância e juventude, de intervenção obrigatória quando manifesto o interesse público da causa, envolver estado de pessoas ou interesses de incapazes, por exemplo.

\section{O Ministério Público e a fiscalização da constitucionalidade e legalidade das normas}

Através da análise histórica da instituição e de sua atual configuração atrás realizada, pudemos vislumbrar que ao Ministério Público sempre coube, de uma forma ou de outra, a defesa da ordem jurídica. E a vaga democrática que felizmente invadiu a maioria dos Estados ocidentais - acentuadamente, nos últimos tempos, os de origem e tradição latinas-, exigiu ali também um MP forte e independente com atribuições e legitimidade para a defesa da legalidade democrática, que começa, sem dúvida, com a defesa da própria Constituição. É o que ocorreu com Portugal e Brasil.

Aqui, antes de mais nada, é oportuno salientar que a fim de alcançar o objetivo do presente trabalho, ou seja, a abordagem da atuação do MP português na fiscalização da constitucionalidade (e também da legalidade) das normas jurídicas, à luz, também, da 162

Revista de Direito PúBlico, Londrina, V. 1, N. 1, P. 155-180, JAN./ABR. 2006. 
jurisprudência hodierna do Tribunal Constitucional, nos deteremos pontualmente no sistema jurídico-constitucional de Portugal, incursionando apenas ao final e superficialmente pelo direito brasileiro, no intuito ao menos trazer traços suficientes para o paralelismo comparativo entre os dois ordenamentos. E a tarefa se afigura tão mais fácil, na medida em que os fundamentos do controle de ambos os países são muito semelhantes.

Partamos, então, para o exame das disposições da Constituição da República Portuguesa que formalmente se referem a poderes do MP nesta matéria, nomeadamente do Título I (Garantia da Constituição) da Parte IV (Garantia e revisão da Constituição), a saber:

- o n. 3 do Art. 280., que prevê o recurso obrigatório para o Ministério Público, quando se tratar de decisões de tribunais que recusem a aplicação de qualquer norma com fundamento na sua inconstitucionalidade (alínea a) do n.o 1), bem como que recusem a aplicação de norma constante de ato legislativo com fundamento na sua ilegalidade por violação de lei com valor reforçado (alínea a) do n.․2);

- o n. 5 do Art. 280.ํ, que prevê igualmente o recurso obrigatório para o MP perante o Tribunal Constitucional das decisões dos tribunais que apliquem norma anteriormente julgada inconstitucional ou ilegal pelo próprio Tribunal Constitucional.

Para além disso - que concerne à fiscalização concreta da constitucionalidade ou legalidade da norma na sua aplicação ao caso sub judice -, tem-se presente o poder político do Procurador-Geral da República para desencadear a fiscalização abstrata, ou em tese, da constitucionalidade e da legalidade de normas em geral, consoante a alínea e) do n.․ 2 do Art. 281.․

Importa, aqui, tecer algumas rápidas considerações sobre noções elementares acerca dos tipos de fiscalização da constitucionalidade e da legalidade, especialmente no campo da fiscalização concreta.

\section{1 Âmbito da fiscalização concreta da constitucionalidade e da legalidade}

\subsubsection{Fiscalização concreta da constitucionalidade}

A fiscalização concreta da constitucionalidade, também chamada processo incidental - pois não a título principal -, ou ação judicial de inconstitucionalidade, significa 
tanto o emprego concreto do princípio tradicional de fiscalização prévia da constitucionalidade das normas a aplicar a um caso concreto, quanto a manifestação de caráter do juízo como introdução necessária de um certo recurso de inconstitucionalidade perante um tribunal constitucional ${ }^{8}$.

Conveniente, neste ponto, recordarmos os quatro grandes sistemas extraídos do direito comparado que traduzem as possíveis posturas dos tribunais frente às questões de inconstitucionalidade: $a$ ) incompetência para conhecer e, portanto, para decidir - modelo de matriz francesa; b) competência para conhecer e decidir, como qualquer outra questão (naturalmente com recurso para tribunal superior) - modelo norte-americano; $c$ ) competência para conhecer, mas não para decidir, por caber a decisão a um tribunal constitucional - modelo austríaco; d) competência para conhecer e para decidir, com recurso possível ou necessário (conforme os casos) para um tribunal constitucional - modelo português introduzido com a CRP de 1976 e confirmado, com correções, pelas revisões seguintes.

No sistema português, portanto - ao contrário do modelo austríaco -, o incidente de inconstitucionalidade não é um pressuposto da fiscalização abstrata; cuida-se, isto sim, da inconstitucionalidade no caso concreto, cabendo ao tribunal a quo ou ao Tribunal Constitucional apenas conhecerem da questão no caso sub judice, apreciando a sua existência e a sua procedência; jamais, no caso concreto, cuida-se da inconstitucionalidade em abstrato ou em tese ${ }^{9}$.

Observe-se, no entanto, desde já, que este cunho muito peculiar do atual sistema português não obsta à relevância da decisão do Tribunal Constitucional (tal como, antes, da Comissão Constitucional) para além do caso concreto. "Ela é dupla: 1.ํ) porque cabe recurso da decisão de qualquer tribunal que aplique norma anteriormente julgada inconstitucional ou ilegal pelo TC (Art. 280.ำ n.ำ 5); 2.ํ) porque (como já se sabe), quando o Tribunal julga três vezes inconstitucional ou ilegal a mesma norma, pode, de seguida, ser desencadeado

8 FONSECA, Guilherme da. $<$ O Ministério Público e a Constituição 》>. Revista do Ministério Público, Lisboa, n.ㅇ 31, p. 82, 1987.

9 Cf. acórdão n.o 102/84 do Tribunal Constitucional. Apud MIRANDA, Jorge. Manual de Direito Constitucional. 3. ed. Coimbra: Coimbra Editora, 1996, t. 2, p. 437. 
um processo (de fiscalização abstrata) com vista à declaração de inconstitucionalidade ou de ilegalidade com força obrigatória geral (Art. 281으, n. 3, CRP)"10.

Atualmente, considerando as revisões constitucionais culminadas na de 1997, há recurso para o Tribunal Constitucional das seguintes decisões dos tribunais em matéria de constitucionalidade:

a) Decisões que recusem a aplicação de qualquer norma com fundamento na sua inconstitucionalidade, ou seja, por violação de determinada(s) norma(s) ou determinado(s) princípio(s) da Constituição, podendo esta recusa ser, inclusive, implícita, de acordo com o Art. 280.ํ, n.ㅇ 1, alínea a), da CRP, e Art. 70.ํㅡ n.ㅇ 1, alínea a), da Lei do Tribunal Constitucional (Lei n. ㅇ 28/82, de 15 de Novembro);

b) Decisões que apliquem norma cuja inconstitucionalidade haja sido suscitada durante o processo (Art. 280. , n. ㅇ 1, b), CRP; Art. 70.ํ, n.ำ 1, b), LTC);

c) Decisões dos tribunais que apliquem norma anteriormente julgada inconstitucional pelo próprio Tribunal Constitucional (Art. 280.ํ, n.ำ 5, CRP; Art. 70.ำ n.ำ 1, g), LTC), ou anteriormente julgada inconstitucional pela Comissão Constitucional (Art. 70.ำ, n. 1, h), LTC), nos precisos termos em que seja requerida a sua apreciação ao TC.

E, a propósito, insta registrar as seguintes e essenciais considerações:

- Os recursos para o TC são restritos à questão da inconstitucionalidade suscitada (Art. 280., n. 6, CRP; Art. 71.ำ n. 1, LTC);

- A questão suscitada deve surgir nos processos (civil, penal, administrativo, etc.) em curso em tribunal - incidentalmente, e não a título principal - e pode ser alçada à discussão mesmo após a decisão, desde que não transitada, quando seja lícito ainda fazê-lo (v.g. no caso de incompetência absoluta do tribunal) e, por conseguinte, a sua decisão pode não ser uma decisão final, como um despacho saneador;

- A questão da inconstitucionalidade restringe-se a normas que tenham de ser aplicadas na causa e a ela pertinentes, vale dizer, a controvérsia "só pode e só deve ser conhecida e decidida na medida em que haja um nexo incindível entre ela e a questão principal objecto do processo, entre ela e o feito submetido a julgamento" ${ }^{11}$;

10 Idem. Manual de Direito Constitucional, p. 437.
11 Ibidem. Manual de Direito Constitucional, p. 439. 
- A decisão de um tribunal abarca todos os órgãos jurisdicionais, seja qual for sua categoria (natureza jurisdicional do órgão), v.g., jurisdição voluntária, jurisdição de execução de penas, jurisdição de seção disciplinar do Conselho Superior da Magistratura, etc..

\subsubsection{Fiscalização concreta da legalidade}

A fiscalização concreta da legalidade, que também se pode designar por processo de controle incidental, é uma competência herdada do Supremo Tribunal Administrativo (Lei n. 62/77, de 25 de Agosto). À semelhança da fiscalização concreta da constitucionalidade, considerando, outrossim, as revisões constitucionais culminadas com a de 1997, há recurso para o Tribunal Constitucional das seguintes decisões dos tribunais em matéria de legalidade:

a) Decisões que recusem a aplicação de norma constante de ato legislativo com fundamento na sua ilegalidade por violação de lei com valor reforçado (Art. 280., n.ㅇ 2, a), CRP; art. 70., n.o 1, C), LTC);

b) Decisões que recusem a aplicação de norma constante de diploma regional com fundamento na sua ilegalidade por violação do estatuto da região ou de lei geral da República (Art. 280., n.o 2, b), CRP; art. 70.ํ, n.o 1, d), LTC), podendo tal recusa, inclusive, ser implícita, tal qual na situação a seguir;

c) Decisões que recusem a aplicação de norma constante de diploma emanado de um órgão de soberania com fundamento na sua ilegalidade por violação do estatuto de uma região autônoma (Art. 280.ํ, n.ㅇ 2, c), CRP; Art. 70.ํ, n.ㅇ 1, e), LTC);

d) Decisões que apliquem norma cuja ilegalidade haja sido suscitada durante o processo com qualquer dos fundamentos referidos nas alíneas $a$ ), b) e c) do n.․ 2 do Art. 280. da Constituição da República Portuguesa (Art. 280., n.ำ 2, d), CRP; Art. 70.ํ, n.ํ 1, g), LTC);

e) Decisões que apliquem norma anteriormente julgada ilegal pelo próprio Tribunal constitucional (Art. 280., n.으, CRP; Art. 70.ํ, n.ㅇ 1, g), LTC).

E sobre a fiscalização da legalidade são sempre presentes as idéias de que:

- Os recursos para o Tribunal Constitucional são restritos à questão da ilegalidade suscitada (Art. 280., n. 6, CRP; Art. 71, n. 1, LTC); 
- A questão suscitada deve surgir nos processos em curso em tribunal (penal, civil, administrativo, fiscal);

- A questão da ilegalidade respeita a normas constantes de atos legislativos e de diploma regional emanado de um órgão de soberania, com especial destaque para o fundamento da violação do estatuto de uma região autônoma;

- A decisão de um tribunal engloba todos os órgãos jurisdicionais (natureza jurisdicional do órgão).

Por fim, não se deve descuidar dos recursos que recusem, seja por inconstitucionalidade ou por ilegalidade, a aplicação de norma constante de convenção internacional, ato legislativo ou decreto regulamentar, ou a apliquem em desconformidade com o anteriormente decidido sobre a questão pelo Tribunal Constitucional (Art. 280.ํ, n.으 3, CRP; Art. 70., n.ㅇ 1, i), LTC).

\subsection{Legitimidade para recorrer}

Para além do poder ex officio de cada juiz de apreciar a inconstitucionalidade ou a ilegalidade, podem recorrer para o Tribunal Constitucional o Ministério Público e as pessoas que, de acordo com a lei reguladora do processo em que a decisão foi proferida, tenham legitimidade para dele interpor o recurso (Art. 72.ㅇ, n.o 1, LTC), podendo, pois, haver singularidade ou pluralidade de partes.

Especificamente com relação ao Ministério Público, vê-se que possui ele legitimidade para recorrer ora obrigatoriamente, ora facultativamente, o que acaba por conferir ao recurso para o Tribunal Constitucional para o qual está legitimado um caráter misto: não tem somente uma finalidade subjetiva de defesa de direitos e interesses das pessoas, tem também uma finalidade objetiva de defesa da integridade da ordem jurídica.

Assim, é o recurso obrigatório para o Ministério Público nas seguintes hipóteses, já mencionadas en passant anteriormente:

a) quando a norma cuja aplicação tenha sido recusada, por inconstitucionalidade ou ilegalidade, conste de convenção internacional, de ato legislativo ou de decreto regulamentar (Art. 280., n.ㅇ 3, CRP; Art. 72.ำ n.ㅇ 3, 1a parte, LTC);

b) quando seja aplicada norma anteriormente julgada inconstitucional ou ilegal pelo Tribunal Constitucional (Art. 280.ํ, n.o 5, CRP; e Art. 72.ํ, n.ㅇ 3, LTC); 
c) quando seja aplicada norma anteriormente julgada inconstitucional pela Comissão Constitucional, nos precisos termos em que seja requerida a sua apreciação ao Tribunal Constitucional (Art. 72., n.ㅇ 3, LTC, ref. à al. h) do n. 1 do Art. 70. do mesmo diploma);

d) quando seja recusada a aplicação de norma constante de ato legislativo com fundamento na sua contrariedade com uma convenção internacional, ou seja aplicada esta norma em desconformidade com o anteriormente decidido sobre a questão pelo Tribunal Constitucional (Art. 72.ํ, n. 3, LTC, ref. à al. i) do n. 1 do Art. 70. do mesmo diploma).

Tratando-se, contudo, de norma legislativa contrária a convenção internacional, prevê-se uma atenuação à obrigatoriedade do recurso pelo MP, podendo ele abster-se de o interpor de decisões conformes com a orientação que se encontre já estabelecida, a respeito da questão em causa, na jurisprudência do TC (Art. 72.ํ, n.․ 4, LTC).

Por outro lado, o recurso é facultativo para o MP quando for ele parte e, como qualquer outra, tenha legitimidade para dela interpor recurso, de acordo com a lei reguladora do processo em que a decisão foi proferida (Art. 72.ํ, n.ำ 1, b), LTC).

Posteriormente, voltaremos à análise deste assunto pontual à luz da jurisprudência do TC, destacando, desde já - o que realça sobremaneira o pendor subjetivista de defesa de direitos e interesses de pessoas -, que só as partes que hajam suscitado as questões de inconstitucionalidade ou ilegalidade de norma durante o processo podem interpor recurso de decisões que a apliquem (Art. 280.ํ, n.으 4, CRP; Art. 72.ํ, n.으 2, LTC).

Mas, neste tópico atinente à legitimidade, ainda insta consignar as seguintes considerações:

- o direito de recurso para o Tribunal Constitucional é irrenunciável (Art. 73.ํ, LTC), o que reforça o sentido objetivo do instituto relativamente ao Ministério Público, ao contrário do que normalmente ocorre em processo civil, onde até se admite a renúncia antecipada quando proveniente de ambas as partes (Art. 681.․, CPC);

- há, assim, sentido objetivista nas hipóteses da alínea a) do n. 1 do Art. 72. da LTC; e sentido subjetivista nas hipóteses de sua alínea b);

- deve entender-se por convenção internacional, ato legislativo ou decreto regulamentar, tanto atos praticados à sombra da Constituição de 1976, como atos (até com outras designações) praticados à sombra das Constituições anteriores, devendo também, 
por outro lado, abranger-se no decreto regulamentar o decreto regulamentar regional, pelo menos quanto ao de regulamentação de leis gerais da República ${ }^{12}$.

- o recurso interposto pelo Ministério Público aproveita a todos os que tenham

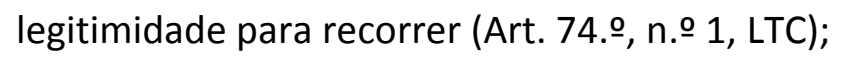

- o recurso interposto por um interessado aproveita aos restantes interessados (Art.

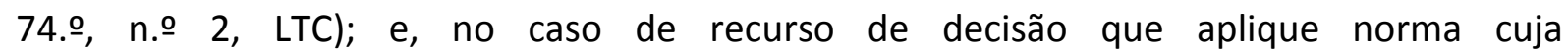
inconstitucionalidade ou ilegalidade tenha sido suscitada, também aproveita aos restantes, nos termos e limites estabelecidos na lei reguladora do processo em que a decisão tiver sido proferida (Art. 74., , n. - 3, LTC);

- não pode haver recurso subordinado, nem adesão ao recurso para o Tribunal Constitucional (Art. 74.ํ, n. 4, LTC). Não pode haver o primeiro (Art. 682. do Código de Processo Civil), porque, quanto à questão da inconstitucionalidade, nunca as partes no processo ficam ambas vencidas: a norma ou é aplicada ou não. No segundo caso - adesão ao recurso (Art. 683.o, n.o 2 a 4, do CPC) -, porque o recurso aproveita sempre aos compartes, passando tudo como se ocorresse litisconsórcio necessário ${ }^{13}$;

- se o Ministério Público deixar de cumprir a obrigação de recurso ou a interpuser fora do prazo, não há meio de superar tal falta, salvo se tiver existido recurso de parte. Tal omissão é irremediável.

\subsection{Tramitação processual dos recursos e alcance das decisões do Tribunal Constitucional}

No intuito de abordarmos o máximo possível relativamente à atuação do Ministério Público em nível de controle da constitucionalidade e da legalidade, passaremos também a elaborar um rápido e resumido esquema da tramitação dos recursos para o Tribunal Constitucional, com particular destaque, uma vez mais, para questões de redobrado interesse para o parquet.

FONSECA, Guilherme da. «< O Ministério Público e a Constituição >>. Op. cit., p. 87.

13 Cf. MIRANDA, Jorge. Manual de Direito Constitucional. Op. cit., p. 452; e FONSECA, Guilherme da. $<<0$ Ministério Público e a Constituição >>. Op. cit., p. 88. 
Em primeiro lugar, temos de ter sempre em mente que à tramitação dos recursos para o TC são subsidiariamente aplicáveis as normas do Código de Processo Civil, em especial as respeitantes ao recurso de apelação (Art. 69. , LTC).

- O recurso é interposto, como qualquer outro, através de um requerimento, dirigido ao Presidente do TC, em que há manifestação da vontade de recorrer àquela Corte;

- o prazo de interposição do recurso é de 10 dias e interrompe os prazos para interposição de outros que porventura caibam da decisão, os quais só podem ser interpostos depois de cessada a interrupção (Art. 75.ํ, n.o 1, LTC);

- interposto recurso ordinário, mesmo que para uniformização de jurisprudência, que não seja admitido com fundamento em irrecorribilidade da decisão, o prazo para recorrer para o Tribunal conta-se do momento em que se torna definitiva a decisão que não admite recurso (Art. 75.ㅇ, n.ㅇ 2, LTC);

- o tribunal que tiver proferido a decisão recorrida aprecia a admissão do recurso (Art. 76.o, n.o 1, LTC), fixando-lhe os efeitos e o regime de subida. A decisão que admita o recurso ou the determine o efeito não vincula o TC e as partes só podem impugná-la nas suas alegações (Art. 76.ํ, n.ㅇ 3, LTC);

- do despacho que indefere o requerimento de interposição do recurso ou retenha a sua subida cabe reclamação para o TC (Arts. 76.ำ n.ㅇ 4, e 77.ํ, n.ำ 1, LTC). A reclamação é um incidente julgado com rapidez: o prazo de vista é de 10 dias para o relator e de 5 para o Ministério Público e os restantes juízes, podendo ser dispensada a vista para estes últimos se o relator entender que a questão é simples, promovendo a imediata inscrição do processo, em tabela, lavrando o Tribunal decisão sumária (Art. 77.ํ, n. 2 e 3, LTC). 0 julgamento é feito em seção do TC (há duas seções não especializadas com 6 juízes cada, além do Presidente). A decisão do TC não pode ser impugnada e, se revogar o despacho de indeferimento, faz caso julgado (coisa julgada) quanto à admissibilidade do recurso (Art.

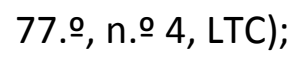

- o Presidente pode, com a concordância do Tribunal, determinar que o julgamento se faça com intervenção do plenário, quando o considerar necessário para evitar divergências jurisprudenciais ou quando tal se justifique em razão da natureza da questão a decidir (Art. 79.-A, n.ำ 1, LTC); 
- ressalte-se que as alegações do recurso são sempre produzidas no Tribunal Constitucional, mesmo quando se trate de recurso obrigatório (Art. 79., LTC);

- o recurso interposto de decisão que não admita outro, por razões de valor ou alçada, tem os efeitos e o regime de subida do recurso que no caso caberia se o valor ou a alçada o permitissem (Art. 78. ํ, n. ㄴ 1, LTC);

- o recurso interposto de decisão da qual coubesse recurso ordinário, não interposto ou declarado extinto, tem os efeitos e o regime de subida deste recurso (Art. 78. , n.․ 2, LTC);

- o recurso interposto de decisão proferida já em fase de recurso mantém os efeitos e o regime de subida do recurso anterior, salvo no caso de ser aplicável o disposto no número 2 do Art. 78. da LTC (Art. 78.ํ, n.o 3, LTC);

- nos restantes casos, como regra geral e supletiva, o recurso tem efeito suspensivo e sobe nos próprios autos (Art. 78.ํ, n. ㄴ, LTC);

- se o Tribunal vier a julgar a questão da inconstitucionalidade ou da ilegalidade em sentido divergente do anteriormente adotado quanto à mesma norma, por qualquer das suas seções, dessa decisão cabe recurso para o plenário do Tribunal, obrigatório para o Ministério Público quando intervier no processo como recorrente ou recorrido (Art. 79.--D, n.o 1, (LTC) $)^{14}$;

- a decisão do recurso faz caso julgado no processo quanto à questão de inconstitucionalidade ou ilegalidade suscitada (Art. 80.ํ, n.․ 1, LTC);

- se o TC der provimento ao recurso, ainda que só parcialmente, os autos baixarão ao tribunal de onde provieram, a fim de que este, consoante for o caso, reforme a decisão ou a mande reformar em conformidade com o julgamento sobre a questão da inconstitucionalidade ou da ilegalidade (Art. 80., n. 2, LTC). “O Tribunal Constitucional não substitui, portanto, a decisão recorrida por aquela que deveria ser emitida, e tão pouco a anula. É um sistema intermédio de recurso o adoptado, um sistema em que o Tribunal Constitucional ordena ao tribunal recorrido que profira nova decisão com o conteúdo por ele prefixado"15; 14 V. acórdão n.o 340/90, de 19 de Dezembro, in Diário da República, 2a série, n. 65, de 19 de Março de 1990.
15 MIRANDA, Jorge Manual de Direito Constitucional. Op. cit., p. 455. 
- transitada em julgado a decisão que não admita o recurso ou the negue provimento, transita também a decisão recorrida, se estiverem esgotados os recursos ordinários, ou começam a correr os prazos para estes recursos, no caso contrário (Art. 80.ำ, ก.ㅇ 4, LTC).

\subsection{Passagem da fiscalização concreta à fiscalização abstrata}

Vejamos, também brevemente, esta questão, onde uma vez mais tem papel preponderante o Ministério Público.

Por imposição de um princípio de economia, tendente a evitar que se multipliquem as decisões semelhantes ou idênticas do TC, bem como de um princípio de segurança jurídica e de igualdade de tratamento das pessoas colocadas em idênticas condições, há a possibilidade de declaração da inconstitucionalidade ou ilegalidade da norma com força obrigatória geral, desde que tenha sido por ele assim julgada em três casos concretos (Art. 281., n.․ 3, CRP; Art. 82.ㅇ, LTC).

O processo destinado à apreciação e declaração, no entanto, não é automático ao terceiro caso, devendo ser desencadeado por iniciativa de qualquer dos juízes do TC ou do Ministério Público.

O processo é organizado com base nas cópias dos correspondentes acórdãos do TC, com as três decisões, o qual é concluso ao Presidente, seguindo-se os termos do processo de fiscalização abstrata sucessiva da constitucionalidade ou da legalidade previsto na Lei do Tribunal Constitucional, com possibilidade, designadamente, de ser ouvido o órgão autor da norma e de serem obtidos mais elementos e informações.

\subsection{Sistema brasileiro de controle da constitucionalidade}

Como anteriormente salientado, trazemos, agora, alguns apontamentos sobre o sistema de controle de constitucionalidade no Brasil, nomeadamente quanto à atuação do Ministério Público nesse âmbito.

A Constituição Federal de 1988 reconhece também duas formas de inconstitucionalidade: a inconstitucionalidade por ação e a inconstitucionalidade por omissão (Art. 102, I, a, e III, $a, b$ e $c$; e art. 103 e parágrafos), tendo por fundamentos 
aqueles mesmos da Constituição da República Portuguesa. Aliás, foi nesta que a vigente Carta brasileira inspirou-se ao adotar a inconstitucionalidade por omissão (Art. 103, § 2. ${ }^{16}{ }^{16}$.

$\mathrm{O}$ atual sistema jurisdicional brasileiro é essencialmente o mesmo instituído com a primeira Constituição da República (1891) que, sob a influência do constitucionalismo norteamericano, acolhera o critério de controle difuso por via de exceção, que perdura até nossos dias.

É óbvio que as constituições posteriores foram, aos poucos, introduzindo novos elementos, de maneira a afastar-se daquele puro critério difuso, com a adoção de aspectos do método concentrado.

Interessa, aqui, incorrermos nessa evolução histórica, mormente para que se visualize o papel preponderante que sempre coube ao Ministério Público nessa área, até bem pouco tempo, aliás, possuidor, através do Procurador-Geral da República, de legitimidade exclusiva para propor a ação direta de inconstitucionalidade de lei ou ato normativo federal ou estadual.

Assim, a Constituição de 1934, não obstante manter as regras do critério difuso em seu Art. 76, $a$ e $b$, trouxe três relevantes inovações: a ação direta de inconstitucionalidade interventiva; a regra de que só por maioria absoluta de votos dos seus membros os tribunais poderiam declarar a inconstitucionalidade de lei ou ato do Poder Público; e a atribuição ao Senado Federal de competência para suspender a execução, no todo ou em parte, de lei ou ato declarado inconstitucional em decisão definitiva. A Emenda Constitucional n. 0 16, de 6 de Dezembro de 1965, vigente a Constituição de 1946, criou uma nova modalidade de ação direta de inconstitucionalidade de caráter genérico, ao atribuir ao Supremo Tribunal Federal competência para processar e julgar originariamente a representação de inconstitucionalidade de lei ou ato normativo, federal ou estadual, apresentada pelo Procurador-Geral da República (Art. 20, k), bem como estatuiu que a lei poderia estabelecer processo, de competência originária do Tribunal de Justiça (tribunal superior existente em cada Estado da federação), para declarar a inconstitucionalidade de lei ou ato municipal, em conflito com a Constituição Estadual (Art. 19). Já a Constituição de 1969 instituiu a ação direta interventiva para a defesa de princípios da Constituição Estadual, promovida pelo

16 SILVA, José Afonso da. Curso de Direito Constitucional Positivo. Op. cit., p. 48-49. 
Chefe do Ministério Público do Estado (Procurador-Geral de Justiça) e de competência também do respectivo Tribunal de Justiça (Art. 15, § 3.ำ $d$ ).

Com o advento da Constituição democrática de 1988, muito se mudou, e para melhor, no sistema da Carta de 1969, que muito bem traduzia, diga-se de passagem, o espírito ditatorial da época (ditadura militar: 1964-1985). E isto se vislumbrava, v.g., em matéria de controle da constitucionalidade, como visto, na legitimação exclusiva do Procurador-Geral da República, então cargo de confiança do Chefe do Executivo e por ele demissível ad nutum, o que tornava inconcebível conferir-lhe privativamente tão importante instrumento de defesa da legalidade constitucional.

A Constituição de 1988 introduziu, assim, mais duas inovações: previu a inconstitucionalidade por omissão (Art. 103, § 2.ํ) e ampliou a legitimação para a propositura da ação direta de inconstitucionalidade, por ação ou omissão (Art. 103). Neste passo, a legitimação cabe não só ao Procurador-Geral da República, mas também, concorrentemente, ao Presidente da República, às mesas do Senado Federal, da Câmara dos Deputados e das Assembléias Legislativas dos Estados, ao Governador de Estado, ao Conselho Federal da Ordem dos Advogados do Brasil, a partido político com representação no Congresso Nacional e a confederação sindical ou entidade de classe de âmbito nacional.

Em resumo: pela Constituição vigente, temos a inconstitucionalidade por ação ou omissão, e o controle de constitucionalidade é o jurisdicional, confirmando os critérios difuso e concentrado, este de competência do Supremo Tribunal Federal. Este, a despeito de ter visto reduzida sua competência à matéria constitucional, não é uma Corte Constitucional, como, v.g., o Tribunal Constitucional português, pois não é o único órgão jurisdicional competente para o exercício da jurisdição constitucional, porquanto o sistema brasileiro continua fundado no critério difuso, que autoriza qualquer tribunal e juiz a conhecer da prejudicial de inconstitucionalidade por via de exceção. Temos, assim, o exercício do controle por via de exceção e por ação direta de inconstitucionalidade. Segundo o controle por exceção, qualquer interessado poderá suscitar a questão de inconstitucionalidade, em qualquer processo, seja de que natureza for, qualquer que seja o juízo. A ação direta de inconstitucionalidade compreende três modalidades: 1) a interventiva, que pode ser federal, por proposta exclusiva do Procurador-Geral da República e de competência do STF (Arts. 36, VII; 102, I, a; e 129, IV, CF), ou estadual, por proposta do Procurador-Geral de Justiça do 
Estado (Arts. 36, IV; e 129, IV, CF). Essas ações são chamadas interventivas porque destinadas a promover a intervenção federal em Estado ou do Estado em Município, conforme o caso; 2) a genérica: a) de competência do STF, tendente a obter a decretação de inconstitucionalidade, em tese, de lei ou ato normativo, federal ou estadual, sem outro objetivo senão expurgar da ordem jurídica a incompatibilidade vertical, visando, portanto, exclusivamente à defesa do princípio da supremacia constitucional (Arts. 102, I, a, e 103, incisos e $\S 3 . \circ, \mathrm{CF}) ;$ b) de competência do Tribunal de Justiça em cada Estado, visando a declaração de inconstitucionalidade, em tese, de leis ou atos normativos estaduais ou municipais em face da Constituição Estadual (Art. 125, § 2.o , CF), conforme previsão desta; 3) a supridora de omissão: a) do legislador, que deixa de criar lei necessária à eficácia e aplicabilidade de normas constitucionais, especialmente nos casos em que a lei é requerida pela Constituição; b) do administrador, que não tome as providências necessárias para tornar efetiva norma constitucional (Art. 103, § 2.․․ CF).

A Constituição Federal mantém a regra que vem, como visto, da Constituição de 1934, de acordo com a qual somente pelo voto da maioria absoluta de seus membros ou dos membros do respectivo órgão especial poderão os tribunais declarar a inconstitucionalidade de lei ou ato normativo do Poder Público (Art. 97).

Depreende-se do acima exposto que o constitucionalismo brasileiro estruturou técnica peculiar de controle. "Milita presunção de validade constitucional em favor de leis e atos normativos do Poder Público, que só se desfaz quando incide o mecanismo de controle jurisdicional estatuído na Constituição. Essa presunção foi reforçada pela Constituição pelo teor do Art. 103, § 3.ำ que estabeleceu um contraditório no processo de declaração de inconstitucionalidade, em tese, impondo o dever de audiência do Advogado-Geral da União, que obrigatoriamente defenderá o ato ou texto impugnado" ${ }^{17}$.

Quanto aos efeitos, a sentença que decide a inconstitucionalidade na via de exceção ou indireta - por ser um incidente processual que busca a simples verificação da existência ou não do vício alegado - reveste-se de caráter declaratório. Faz, assim, coisa julgada no processo e entre as partes, mas não em relação à lei declarada inconstitucional, que continua em vigor, eficaz e aplicável, até que o Senado Federal, por resolução, suspenda sua executoriedade, nos termos do Art. 52, X, da CF. E aqui é criada uma situação

17 SILVA, José Afonso da. Curso de Direito Constitucional Positivo. Op. cit., p. 53-54. 
interessante: relativamente ao caso concreto, a declaração produz efeitos ex tunc, vale dizer, fulmina a relação jurídica fundada na lei inconstitucional desde o seu nascimento. Entretanto, a lei continua eficaz e aplicável, até que o Senado suspenda sua executoriedade através de resolução que só surte efeitos a partir daí, ex nunc.

Já a sentença proferida no processo de ação direta de inconstitucionalidade (genérica) - em razão de ter por objeto a própria questão de constitucionalidade, visando, assim, a retirar a aplicabilidade da norma -, deverá ter eficácia erga omnes.

O efeito da sentença proferida no processo da ação de inconstitucionalidade interventiva, por seu turno - ao não visar apenas à obtenção da declaração de inconstitucionalidade, mas também a restabelecer a ordem constitucional no Estado ou Município, mediante a intervenção -, é verdadeiramente constitutivo, assumindo a decisão, ainda, eficácia geral e obrigatória. Neste caso, a CF estabelece que o decreto de intervenção (do Presidente da República ou do Governador do Estado, conforme o caso) <<se limitará a suspender a execução do ato impugnado, se esta medida bastar ao restabelecimento da normalidade >. Ressalte-se, aqui, que a representação interventiva, nos termos dos Arts. 34 e seguintes da CF, pode dar-se para assegurar a observância de princípios constitucionais federais; por recusa à execução de lei federal; para garantir o livre exercício de qualquer dos Poderes estaduais; ou para fazer valer a ordem ou decisão judiciária eventualmente desrespeitada.

Finalmente, quanto aos efeitos da declaração de inconstitucionalidade por omissão, são eles traduzidos no $\S 2$. o do Art. 103 da Carta brasileira: <<declarada a inconstitucionalidade por omissão de medida para tornar efetiva norma constitucional, será dada ciência ao Poder competente para a adoção das providências necessárias e, em se tratando de órgão administrativo, para fazê-lo em trinta dias >. Daí conclui-se que a respectiva sentença é declaratória quanto ao reconhecimento da inconstitucionalidade por omissão, porém não é meramente declaratória, porque dela decorre um efeito ulterior de natureza mandamental, no sentido de exigir do Poder competente a adoção das providências necessárias ao suprimento da omissão.

Especificamente sobre a atuação do Ministério Público nesse âmbito, podemos acentuar, então, em suma: 
a) compete ao Ministério Público a função institucional de promover a ação de inconstitucionalidade e a representação para fins de intervenção da União e dos Estados, nos casos previstos na Constituição (Art. 129, IV, CF);

b) o inciso VI do Art. 103 da CF confere ao Procurador-Geral da República a propositura da aludida ação direta de inconstitucionalidade;

c) tendo em vista o modelo federal, os Estados, em suas correspondentes Cartas, através de expressa delegação do § 2.o do Art. 125 da CF, instituíram a representação de inconstitucionalidade de leis ou atos normativos estaduais ou municipais em face das Constituições Estaduais, também com legitimação concorrente para agir atribuída a vários órgãos, dentre os quais, como não poderia deixar de ser, os respectivos ProcuradoresGerais de Justiça, Chefes do MP nas unidades federativas (Art. 25, I, LONMP);

d) além da hipótese supra, também cabe ao Chefe do Ministério Público dos Estados a iniciativa na representação interventiva dos Estados nos Municípios (Art. 129, CF; e Art. 25, II, LONMP).

Para uma melhor compreensão do tema relativo à ação de inconstitucionalidade interventiva, onde, como visto, o Ministério Público possui atribuições ativas de relevo, é salutar que se esclareça que, na esfera federal, há dois tipos de intervenção: a espontânea, em que o Presidente da República age de ofício (Art. 84, X, CF), e a provocada. Por sua vez, a intervenção dita provocada pode ser discricionária ou vinculada. Será discricionária quando se der por solicitação do Poder Legislativo ou do Poder Executivo coacto ou impedido (Art. 36, I, CF), pois o Presidente da República se aterá a critérios de oportunidade e conveniência, não estando obrigado a decretá-la, se assim entender que não é o caso. Será vinculada, por sua vez, quando advier de requisição de um dos tribunais superiores indicados na Constituição, ou quando for o caso de provimento de representação interventiva. Será obrigatória a intervenção se for precedida de requisição do Supremo Tribunal Federal, do Superior Tribunal de Justiça ou do Tribunal Superior Eleitoral (Art. 36, I e II, CF); será igualmente obrigatória a expedição do decreto de intervenção quando resultar esta de provimento de representação interventiva emanada do Procurador-Geral da República (Art. 36, III e IV), ou quando resultar de provimento de representação interventiva do interessado, para prover a execução de ordem ou decisão judicial (Art. 35, IV, CF). 
A Constituição distingue, portanto, entre as hipóteses em que a requisição dos tribunais dependa ou não da representação do Procurador-Geral da República (Arts. 35, IV, e 36, I a IV). Assim, incumbe àquele as representações interventivas para assegurar a observância de princípios constitucionais federais (Art. 34, VII, c/c. o Art. 36, III) e por recusa à execução de lei federal (Art. 34, VI, c/c. o Art. 36, IV). Aquelas para garantir o livre exercício de qualquer dos Poderes estaduais (Art. 34, IV) e aquelas decorrentes de desrespeito a ordem ou decisão judicial (Art. 34, VI) é que dependem ora de requisição dos tribunais superiores (Art. 36, I e II), ora, em caso de descumprimento de ordem ou decisão judicial, de representação interventiva do interessado (Art. 35, IV), nesta não mais subsistindo a exclusiva iniciativa do Chefe do Ministério Público.

$\mathrm{Na}$ esfera estadual, há também a intervenção espontânea, em que o Governador agirá oficiosamente, e a provocada. Poderá ser provocada por solicitação do Poder Legislativo ou do Poder Executivo coacto ou impedido (Art. 36, I, CF), ou por requisição direta do Tribunal de Justiça local, se a coação for exercida contra o Poder Judiciário, ou se tratar de desobediência a ordem ou decisão judicial (Art. 36, I e II, CF). Poderá, ainda, ser subseqüente ao provimento de representação interventiva do Procurador-Geral de Justiça do Estado ou do próprio interessado, nos mesmos moldes que ocorrem na esfera federal.

\section{Conclusão}

De tudo quanto exposto, acentuado restou que o perfil moderno do Ministério Público, designadamente em Portugal e no Brasil, traduz-se no papel de defensor do regime democrático e da Constituição, a par de outras relevantes e tradicionais funções sacramentadas ao longo da evolução histórica da instituição.

Essa tarefa desenvolve-se no labutar forense cotidiano de seus agentes, em todas as áreas e níveis de atuação, principalmente porque têm essas mesmas atribuições, hoje, assento constitucional, e para seu desempenho goza o parquet de imprescindíveis garantias, tais como liberdade, autonomia e independência funcional de seus órgãos, bem como de instrumentos legais eficazes.

Não há dúvida, portanto, de que existe uma íntima relação, delimitada em lei, entre o equilíbrio da vida social e o fiel exercício das funções próprias do Ministério Público que, como órgão de soberania do Estado, só atinge sua destinação em meio essencialmente 
democrático, donde se conclui que a defesa deste acaba por ser a defesa do sentido de ser da própria instituição.

\section{Referências}

CANOTILHO, J. J. Gomes. Direito Constitucional e Teoria da Constituição. 2. ed. Coimbra: Almedina, 1998.

CANOTILHO, J. J. Gomes; MOREIRA, Vital. Constituição da República Portuguesa Anotada. 3. ed. Coimbra: Coimbra Editora, 1993.

CHAVES, Eduardo Arala. O Ministério Público: o seu passado e o seu presente. Boletim da Faculdade de Direito da Universidade de Coimbra, v. 56, 1981.

FONSECA, Guilherme da. O Ministério Público e a Constituição. Revista do Ministério Público, Lisboa, n. 31, 1987.

MAZZILLI, Hugo Nigro. Manual do Promotor de Justiça. 2. ed. São Paulo: Saraiva, 1991.

MIRABETE, Júlio Fabbrini. Processo Penal. 2. ed. São Paulo: Atlas, 1992.

MIRANDA, Jorge. Manual de Direito Constitucional. 3. ed. Coimbra: Coimbra Editora, 1996, t. 2.

PIERANGELLI, José Henrique. Processo Penal. Bauru: Jalovi, 1983.

REIS, Adalberto dos. Ministério Público (Histórica) .Revista do Ministério Público, Lisboa, n. 66. 1996.

SILVA, José Afonso da. Curso de Direito Constitucional Positivo. 9. ed. São Paulo: Malheiros, 1992.

TOURINHO FILHO, Fernando da Costa. Processo Penal. São Paulo: Saravia, 1982, v. 2.

VELLANI, Mario. Il pubblico ministero nel processo. 2. ed. Bologna [s.n.] 1965. v. 1, t. 1. 
Revista de Direito Público, Londrina, V. 1, N. 1, P. 155-180, JAN./ABR. 2006. 